International Journal of

Health, Medicine and

Nursing Practice

(IJHMNP)

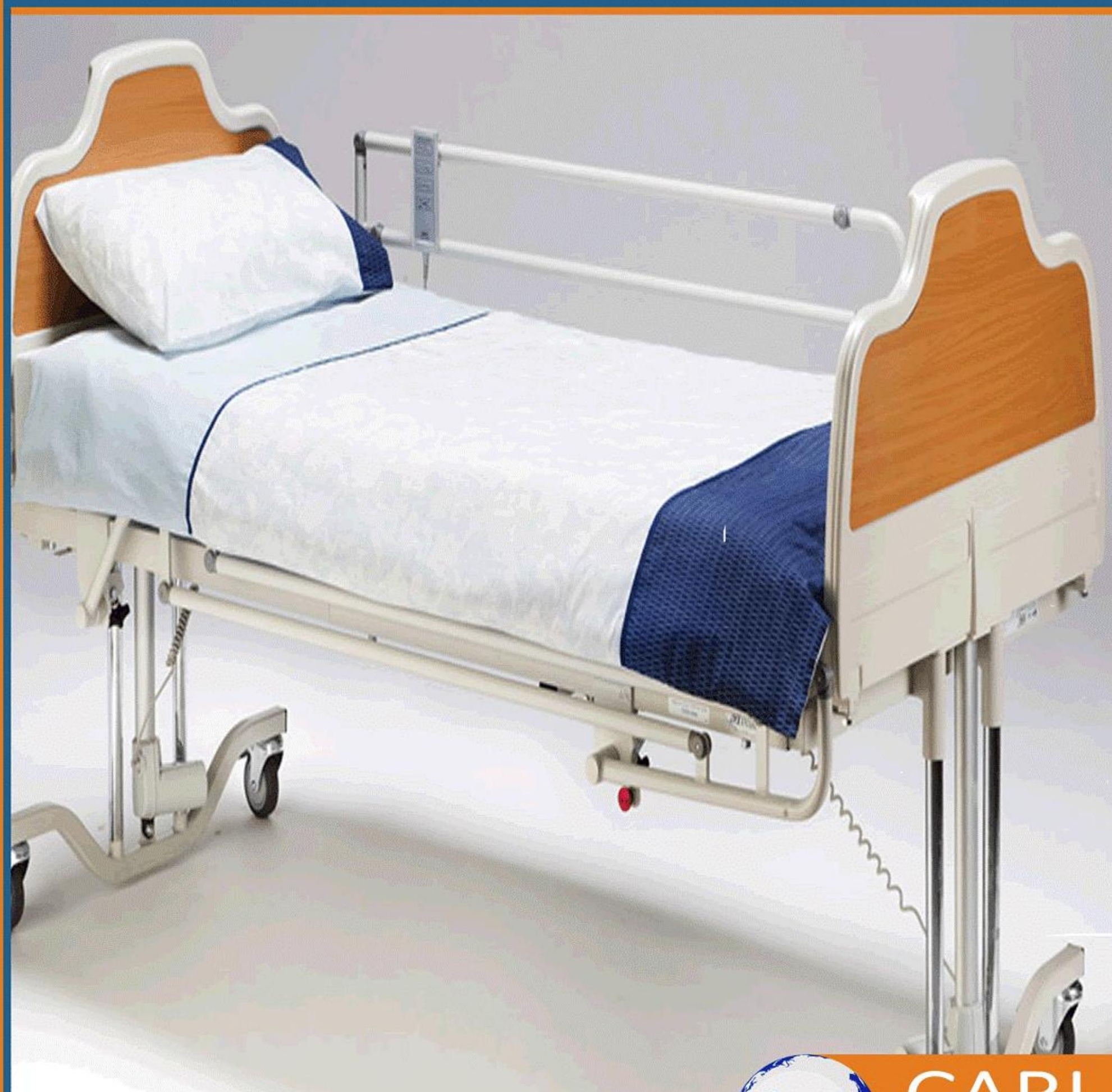




\title{
The Awareness of Oncology Nurses about Chemotherapy based - Extravasation Care
}

\author{
${ }^{1 *}$ Rabia Muhammad Ali, \\ Bscn student, department of LSN, The Universty of Lahore \\ Corresponding Email:rabiarizwan25@gmail.com \\ Kausar Pareveen ${ }^{2}$, Muhammad Hussain ${ }^{3}$, Muhammad Afzal ${ }^{4}$, Farhat Shaheen ${ }^{5}$ \\ ${ }^{2}$ Associate Professor, Department Of LSN, The Universty of Lahore, ${ }^{3}$ Assistant Professor, \\ Department Of LSN, The Universty of Lahore, ${ }^{4}$ Associate Professor Department Of LSN, The \\ Universty of Lahore, Post Graduate LSN Trainee, Department Of LSN, University of Lahore \\ Teaching Hospital \\ *Corresponding Author’s Email: rabiarizwan25@gmail.com
}

\begin{abstract}
Objectives: To assess oncology nurses' awareness of chemotherapy-based extravasation care.

Methodology: The study adopted a cross sectional descriptive study design. One hundred and fifty patients of both gender male and female were included in this study. Using SPSS, data analysis was performed and used to define the corresponding chi-square factor. Graphs and tables provided the details.

Result: Total 150 participants are involved this study $71.7 \%$ were male participants and more than half $62.4 \%$ participants were registered nurses. The academic qualification of mostly participants $64.4 \%$ were diploma nurses and have 1-4 year of experience. $38.0 \%$ percent of participants were engaged in a hospital-based extravasation education program. and $62.0 \%$ were not. Only $40 \%$ of nurses want to continue their extravasation education in the hospital.

Conclusion: Likely, the recent research serves as the basis of experience and expertise of extravasation treatment for oncology nurses. Surprisingly, nurses' understanding of management methods was woefully lacking. This may have an effect on the level of care given to patients with the aid of extravasation Education, lectures, and conferences are held on a regular basis.
\end{abstract}

Key word: Awareness, Oncology, Chemotherapy, extravasation. 


\section{INTRODUCTION}

\section{Background}

Cancer is the leading cause of death globally, with more than 10 million patients diagnosed with the disease per year and 6 million deaths. Pakistan has a much higher disease rate than developing countries. Due to the lack of a daily cancer registry scheme at the national level in Pakistan, existing data on cancer incidence is unavailable; however, according to the most recent available estimates from 2010, the incidence rate including all disorders is 132.4/100,000 of males and 133.0/100,000 for females. Pakistan lacks the economic and physical capital needed to treat cancer, particularly in its advanced stages. When there is a rise in patient volume, there is a shortage of nurses, especially oncology registered nurses, resulting in such a patient - nurse ratio of 1:313. Nurses are overworked as a result of this, and due to scarce budgets, they do not have adequate opportunities to further their knowledge and expertise in their field (Hameed, Javed et al. 2019). By 2020, it is projected that 15 million new cases will be recorded per year (Azoulay, Schellongowski et al. 2017)

Chemotherapy, radiotherapy, surgery, and bone marrow transplantation are among the medical options available to cancer patients. As a result, they suffer from a variety of short and the long problems, like dental problems. Risk of OM varies depending on the type of cancer and the treatment method used. A heavy dose of systemic chemotherapy is often linked to this complication. The prevalence of oral mucositis in people with cancer varies among 30 and 75 percent. (Ferlay, Soerjomataram et al. 2015). The theory and most widespread mode of medical methods is the application of chemotherapy. More than one hundred thousand chemotherapy infusions are done worldwide every day (Al Qadire and Al Khalaileh 2016).

Administration of chemotherapy is the most common and widely used treatment modality. Per day, more than one million chemotherapy infusions were conducted all over the world Despite of how effective chemotherapy is, it can have a number of side effects that can impair the recovery schedule, standard of care, or treatment reaction, like extravasation of chemotherapy (Somayaji, Reddy et al. 2018).

Numbers of clinical manifestations with extravasation of chemotherapy, like redness, swelling, nausea, necrosis, discomfort and burning feeling. Resistance during drug infusion, inadequate infusion, and decreased blood return can also be seen as predictors of extravasation. To avoid, diagnose and minimize chemotherapy-related extravasation at an early level, nurses that work in oncology (as providers of bedside care) should be mindful of risk factors, treatment and prevention steps for extravasations. In addition, continuing instruction of oncology nurses on new evidencebased recommendations on the treatment of chemotherapy is encouraged (Agbessi, Arrob et al. 2015).

Chemotherapy would be a widely recommended cancer therapies, with complex treatment regimens and high-tech tools. A shortage of personnel expertise and preparation leads to tragic incidences such as over doses of chemotherapy, inaccurate dosage estimates, incorrect transfusion paths that often end in the death of the patient. In the past, experiments have been undertaken to test the awareness and temperament of nurses in various specialties and have demonstrated that nurses can develop knowledge with the help of education (Madden, C. J. N. e. t. et al.2016). 
In order to ensure the welfare of all patients' lives and their own safety at work, nurses caring for patients undergoing chemotherapy need specialist knowledge. Because of prescription mistakes, numerous nurses have been discharged from their work. One of the most widely prescribed types of cancer treatment is chemotherapy. Continuing oncology nurse education and preparation serves as the foundation of safe chemotherapy administration and emphasizes the importance and be supportive rather than responsive to adverse effect such as extravasation. The first step is to assess their expertise to establish a formal training curriculum to improve the awareness of nurses about extravasation. (Papa, Kampitsi et al. 2015).

\section{Literature Review}

Extravasation in patients with irreversible local chemotherapy can cause serious harm to patients with injuries and handicaps, according to Onesti MG, Carella S, Fioramonti P, Scuderi N Chemotherapy. Scientific proof standardization on extravasation regulation is missing, and often organizations do not carry out appropriate protocols to stop the more serious Injuries. Their goal was to study the treatment and prevention of accidents from ascites, proposing an effective treatment procedure along with a literature analysis. From 545 cases were examined (age scale, 587 years; 282 and 263 women) from January 1994 to December 2015 (Onesti, Carella et al. 2017).

Pluschnig U, Haslik W, Bayer G, Soleiman A, Bartsch R, Lamm W, et al. 2015 Extravasation of 169 patients with antineoplastic agents and assessment in a single research field of the effectiveness of their interdisciplinary treatment. Conservative treatment was effective in 155 out of 169 patients (91.7 percent), while surgical intervention was required in 14 patients (8.3 percent). In 6 patients, cytotoxic compound extravasation occurred after infusion via the central PortA-Cath system (3.5 percent). Extravasation of anthracycline and mitoxantrone irritant or vesicant cytotoxicants $(26.1 \%$, mostly epirubicin: $\mathrm{N}=38$ or $22.5 \%$ ) occurred more commonly. The second most popular drug class are Compounds of platinum (oxaliplatin: $\mathrm{N}=22$ or $13.0 \%$, cisplatin: $\mathrm{N}=18$ or $10.7 \%$ ) in order of extravasation frequency, Vinca alkaloids (vinorelbine: $\mathrm{N}=20$ or 11,8\%) and taxes (docetaxel: $\mathrm{N}=13$ or $7,7 \%$, paclitaxel: $\mathrm{N}=6$ or $3,6 \%$ ) followed. The compound contains a comprehensive overview of the extravasated compounds and the frequency of extravasation and is described by drug class. Extravasated cytotoxic compounds were not detected in 25 cases (14.8 percent). This was due to paired sequential combination chemotherapy administration (Pluschnig, Haslik et al. 2015).

The purpose of Custódio CS is to evaluate progress over the course of treatment in peripheral veins used in breast cancer patients for chemotherapy infusion, and to clarify care and advice on the selection of venous access for CT infusion. Peripheral intravenous anticancer therapy requires the presence of reliable access to infusion and adequacy to maintain quality of treatment. For this, a thorough examination of the patient's peripheral venous access is important, determining the possible risks of phlebitis, extravasation, as well as anxiety and discomfort. There is no greater limitation of vascular access for therapy in patients undergoing complete or modified mastectomy who have suffered axillary node detachment, thereby requiring greater attention from the infusion care team (Custódio, C. d. S. 2016).

Pérez Fidalgo JA, García Fabregat L, Cervantes A, et al Guidelines for 2018 given in cooperation with the European Oncology Nursing Community by the European Society for Medical Oncology 
(EONS). The method of extravasation is the unintended leaking of some substance (fluid or drug) into the surrounding tissue. Extravasation, in terms of cancer treatment, leads to an accidental. Chemotherapy penetration in to dermal or subdermal areas underlying the Site of intra-vein or intra-arterial administration. Extravasated narcotics are graded according to As 'vesicant', 'irritant' and 'nonvesicant' to their capacity for causing harm (Fidalgo, Fabregat et al. 2015)

\section{Problem statement}

Chemotherapy is a form of chemical drug therapy that is used to kill fast-growing cells in the body. However, there are many hazards and complications involved with this procedure, including tissue injury, altered limb function, discomfort, and a lower quality of life. Nurses play an important part in the prevention, detection, and management of complications. As a result, oncology nurses must be trained in order to improve their skills.

\section{The study objective will be:}

To assess awareness of oncology nurses' about chemotherapy based - extravasation care.

\section{OPERATIONAL DEFINITIONS}

KNOWLEDGE: In this study, knowledge is considering awareness of it will be measured through a 23-item multiple-choice question adopted from the Knowledge Questionnaire (Mileder, Gressl et al. 2019).

\section{HYPOTHESIS}

\section{Null Hypothesis $\mathrm{H}_{0}$ :}

There is no effect of awareness of oncology nurses' about chemotherapy based - extravasation care.

\section{Alternative Hypothesis H1:}

There is an effect of awareness of oncology nurses' about chemotherapy based - extravasation care.

\section{MATERIALS AND METHODS}

Study Designs: A cross sectional descriptive study design

Setting: The setting will be the General Hospital Lahore.

Duration of Study: 4 months after the approval of synopsis

Sample Size: sample size calculated from base article. Which is 150 .

The sample size of the study was 150 nurses significant level 0.05

$\mathrm{N}=240$

Sample size determined by the formula of Slovin

$\mathrm{n}=\mathrm{N} / 1+\mathrm{N}(\mathrm{e})^{2}$

$\mathrm{n}=240 / 1+240(0.05)^{2}$

$\mathrm{n}=240 / 1+240(0.0025)$ 
International Journal of Health, Medicine and Nursing Practice ISSN 2710-1150 (Online)

$\mathrm{n}=240 / 1+0.6$

$\mathrm{n}=240 / 1.6$

$\mathrm{n}=150$

Sampling Technique: Simple random sampling

Sample Selection: Selected General Hospital Lahore

Inclusion Criteria: Inclusion Criteria: The participant will be included in this study who:

Age: 25-30years

31-35 years

36-40 years

41-45 years

Above 45yers

Gender: Male and Female

Education: diploma, Bachler or postgraduate

Experience of problems: General hospital Lahore

Willingness to participate: Only Willing participant

Exclusion Criteria: The participant will be excluded in this study who:

- Professional of this care.

- Have already received any educational training on this topic.

\section{ETHICAL CONSIDERATIONS}

- Written informed consent (attached) will be taken from all these participants.

- All information and data collection will be kept confidential.

- Participants will remain anonymous throughout the study.

- The subjects will be informed that there are no disadvantages or risks to the procedure of the study.

- They will also be informed that they will be free to withdraw at any time during the process of the study.

- The potential benefit of the study for the participants will be an increase in knowledge regarding chemotherapy and related extravasation care.

- We will do everything we can to protect the privacy of participants. The identity of the participant will not be revealed in any publication resulting from this study.

- Reassure the participants that they can withdraw their consent to participate at any time. They will not be penalized in any way should they decide not to participate or to withdraw from this study. 
International Journal of Health, Medicine and Nursing Practice

ISSN 2710-1150 (Online)

Vol. 3, Issue No. 3, pp 44- 57, 2021

www.carijournals.org

\section{DATA COLLECTION PROCEDURE}

\section{Recruitment:}

The study participants will be recruited through the process of convenience sampling techniques. A meeting will be arranged with all the eligible participants. In which the researcher will personally explain the study purpose, procedure, and benefits to the participant. In the meeting, participant's questions regarding the study will clear. Demographic data will be collected through face to face intervention and the knowledge of client will be assessed through instrument, Assessment including questionnaires, observation, focus groups, and interviews.

\section{Study Variables:}

1. Awareness will be measured through 23-item multiple-choice questions adopted from Knowledge Questionnaire.

\section{Methods for Collection of Data:}

Facilitator evaluators will be trained regarding the scoring of each scale data collection. The data will be collected after the approval of the synopsis at the given setting.

\section{ANALYSIS PROCEDURE}

The data analysis will be made using the Statistical Package for the Social Sciences (SPSS) version 25 software to predict the differences in the outcome variables. The frequencies and percentages will be calculated for qualitative variables whereas mean and standard deviation will be calculated for quantitative variables. Sample chi- square test will be used for comparing the mean and significance different will be measured on $\mathrm{P}$ value $<0.05$.

\section{RESULTS}

Table 1: Demographic characteristic of the participants

\begin{tabular}{|l|l|l|l|}
\hline$\%$ & Frequency & Demographic characteristic & Sr\# \\
\hline & & Age & 1 \\
\hline $44.3 \%$ & 66 & $25-30$ years & \\
\hline $23.5 \%$ & 35 & $31-35$ years & \\
\hline $18.1 \%$ & 27 & $36-40$ years & \\
\hline $10.1 \%$ & 15 & $41-45$ years & \\
\hline $4.0 \%$ & 6 & Above 45 years & \\
\hline $\mathbf{1 0 0 \%}$ & $\mathbf{1 5 0}$ & Total & 2 \\
\hline & & Gender & \\
\hline $71.7 \%$ & 92 & Male & \\
\hline $38.3 \%$ & 57 & Female & 3 \\
\hline $\mathbf{1 0 0 \%}$ & $\mathbf{1 5 0}$ & Total & \\
\hline & & Job tittle & \\
\hline $20.8 \%$ & 31 & Practical Nurse & \\
\hline $62.4 \%$ & 93 & Registered Nurse & \\
\hline
\end{tabular}


International Journal of Health, Medicine and Nursing Practice ISSN 2710-1150 (Online)

Vol. 3, Issue No. 3, pp 44- 57, 2021

www.carijournals.org

\begin{tabular}{|c|c|c|c|}
\hline $9.4 \%$ & 14 & In charge Nurse & \\
\hline $7.4 \%$ & 11 & Unit Manager & \\
\hline \multirow[t]{2}{*}{$100 \%$} & 150 & Total & \\
\hline & & Academic qualification level & 4 \\
\hline $64.4 \%$ & 94 & Diploma & \\
\hline $22.8 \%$ & 34 & Bachelor & \\
\hline $12.8 \%$ & 19 & Postgraduate & \\
\hline \multirow[t]{2}{*}{$100 \%$} & 150 & Total & \\
\hline & & Experience in oncology field (years) & 5 \\
\hline $38.0 \%$ & 58 & $1-2$ years & \\
\hline $28.0 \%$ & 38 & $3-4$ years & \\
\hline $25.0 \%$ & 34 & $5-6$ years & \\
\hline $7.0 \%$ & 14 & $7-8$ years & \\
\hline $2.0 \%$ & 4 & $9-10$ years & \\
\hline \multirow[t]{2}{*}{$100 \%$} & 150 & Total & \\
\hline & & $\begin{array}{l}\text { Desire to participate in a hospital-based extravasation } \\
\text { education program. }\end{array}$ & 6 \\
\hline $40.0 \%$ & 59 & Yes & \\
\hline $60.0 \%$ & 90 & No & \\
\hline \multirow[t]{2}{*}{$100 \%$} & 150 & Total & \\
\hline & & $\begin{array}{l}\text { Have you attended a hospital-based extravasation } \\
\text { enrichment program? }\end{array}$ & 7 \\
\hline $38.0 \%$ & 57 & Yes & \\
\hline $62.0 \%$ & 92 & No & \\
\hline $100 \%$ & 150 & Total & \\
\hline
\end{tabular}

Above table show that mostly $71.7 \%$ were male participants and more than half $62.4 \%$ participants were registered nurses. The academic qualification of mostly participants $64.4 \%$ were diploma nurses and have 1-4 year of experience. Just $40 \%$ of nurses want to resume their extravasation education in the hospital. $40 \%$ participants were show desire that they want to learn more education program regarding extravasation in hospital. $38.0 \%$ of participants were participating in a hospitalbased extravasation enrichment program. and $62.0 \%$ were not. 
International Journal of Health, Medicine and Nursing Practice ISSN 2710-1150 (Online)

Vol. 3, Issue No. 3, pp 44- 57, 2021

$\underline{\text { www.carijournals.org }}$

Table 2: Knowledge of definitions, signs and symptoms, and risk factors by nurses

\begin{tabular}{|c|c|c|c|c|c|c|}
\hline \multirow[t]{2}{*}{ Total } & \multicolumn{2}{|c|}{ Wrong Answer } & \multicolumn{2}{|c|}{ Correct answer } & \multirow[t]{2}{*}{ Factors } & \multirow[t]{2}{*}{ Sr \# } \\
\hline & $\%$ & $\begin{array}{l}\text { Frequen } \\
\text { cy }\end{array}$ & $\%$ & $\begin{array}{l}\text { Frequen } \\
\text { cy }\end{array}$ & & \\
\hline $\begin{array}{l}150 \\
(100 \% \\
)\end{array}$ & $52.0 \%$ & 79 & $48.0 \%$ & 70 & $\begin{array}{l}\text { Every liquid that spills into the } \\
\text { surrounding tissue is called a spill. }\end{array}$ & 1 \\
\hline $\begin{array}{l}150 \\
(100 \% \\
)\end{array}$ & $50.7 \%$ & 72 & $49.3 \%$ & 77 & $\begin{array}{l}\text { Chemotherapy infiltration into the } \\
\text { subcutaneous or subdermal tissues } \\
\text { around the intravenous or } \\
\text { intraarterial administration site. }\end{array}$ & 2 \\
\hline $\begin{array}{l}150 \\
(100 \% \\
)\end{array}$ & $46.3 \%$ & 69 & $53.7 \%$ & 80 & $\begin{array}{l}\text { Signs and symptoms } \\
\text { Tingling, burning, discomfort/pain, } \\
\text { swelling, erythema, and/or } \\
\text { blistering are some of the symptoms } \\
\text { that may occur. }\end{array}$ & 3 \\
\hline $\begin{array}{l}150 \\
(100 \% \\
\end{array}$ & $43.0 \%$ & 61 & $57.0 \%$ & 88 & $\begin{array}{l}\text { Marked induration, sometimes } \\
\text { brownish, that lasts days to months } \\
\text { and is accompanied by skin atrophy. }\end{array}$ & 4 \\
\hline $\begin{array}{l}150 \\
(100 \% \\
\end{array}$ & $50.7 \%$ & 77 & $49.3 \%$ & 72 & $\begin{array}{l}\text { After } 1-4 \text { weeks, invasive } \\
\text { ulceration can develop. }\end{array}$ & 5 \\
\hline
\end{tabular}

Above table show that $52.0 \%$ participants gave incorrect answer that any liquid leak into the surrounding tissue and $52.0 \%$ comment that Chemotherapy infiltration into the subcutaneous or subdermal tissue around the intravenous or intraarterial administration site. More than half participants have knowledge about the sign and symptoms show after chemotherapy. Invasive ulceration can occur after 1-4 weeks, according to $49.3 \%$ of participants. 
International Journal of Health, Medicine and Nursing Practice ISSN 2710-1150 (Online)

Vol. 3, Issue No. 3, pp 44- 57, 2021

www.carijournals.org

Table 3: Nurses' knowledge of preventive strategies:

\begin{tabular}{|c|c|c|c|c|c|c|}
\hline Total & \multicolumn{2}{|c|}{ NO } & \multicolumn{2}{|c|}{ Yes } & \multirow[t]{2}{*}{ Preventive strategies } & \\
\hline $\begin{array}{l}150 \\
(100 \%)\end{array}$ & $\%$ & $\begin{array}{c}\text { Freq } \\
\text { uenc } \\
\mathbf{y}\end{array}$ & $\%$ & $\begin{array}{c}\text { Freque } \\
\text { ncy }\end{array}$ & & \\
\hline $\begin{array}{l}150 \\
(100 \%)\end{array}$ & 49.7 & 74 & $\begin{array}{l}50 . \\
3\end{array}$ & 75 & $\begin{array}{l}\text { Site of insertion } \\
\text { Cannula } \\
\text { It's impossible to use central venous if you } \\
\text { don't have peripheral access. }\end{array}$ & 7 \\
\hline $\begin{array}{l}150 \\
(100 \%)\end{array}$ & 47.7 & 71 & $\begin{array}{l}52 . \\
3\end{array}$ & 78 & Use of large veins & 8 \\
\hline $\begin{array}{l}150 \\
(100 \%)\end{array}$ & 46.3 & 69 & $\begin{array}{l}53 . \\
7\end{array}$ & 80 & $\begin{array}{l}\text { Cannulation over joints, the inner elbow, } \\
\text { and the lower extremities should be } \\
\text { avoided. }\end{array}$ & 9 \\
\hline $\begin{array}{l}150 \\
(100 \%)\end{array}$ & 30.7 & 46 & $\begin{array}{l}69 . \\
3\end{array}$ & 104 & $\begin{array}{l}\text { Avoid veins in the antecubital fossa and on } \\
\text { the dorsum of the hand. }\end{array}$ & $\begin{array}{l}1 \\
0\end{array}$ \\
\hline $\begin{array}{l}150 \\
(100 \%)\end{array}$ & 40.0 & 60 & $\begin{array}{l}60 . \\
0\end{array}$ & 90 & $\begin{array}{l}\text { Cannulation should be avoided if } \\
\text { lymphedema is present. }\end{array}$ & $\begin{array}{l}1 \\
1\end{array}$ \\
\hline $\begin{array}{l}150 \\
(100 \%)\end{array}$ & 56.7 & 85 & $\begin{array}{l}43 . \\
3\end{array}$ & 65 & Butterfly' needles must not be used. & $\begin{array}{l}1 \\
2\end{array}$ \\
\hline $\begin{array}{l}150 \\
(100 \%)\end{array}$ & 45.3 & 68 & $\begin{array}{l}54 . \\
7\end{array}$ & 82 & $\begin{array}{l}\text { For long-term infusions (12-24 hours), } \\
\text { central venous access can be used. }\end{array}$ & $\begin{array}{l}1 \\
3\end{array}$ \\
\hline
\end{tabular}

Above table show that 50\% participant have knowledge that central can be used for chemotherapy if peripheral access is difficult and 52.3\% know that large vain must be used. 53.7\% participants have knowledge that cannulation must avoided over joint, or lower extremities and $43.3 \%$ know that butterfly needle not be used during chemotherapy. 
International Journal of Health, Medicine and Nursing Practice ISSN 2710-1150 (Online)

Vol. 3, Issue No. 3, pp 44- 57, 2021

www.carijournals.org

Table 3: Nurses' Knowledge of extravasation management guideline:

\begin{tabular}{|c|c|c|c|c|c|c|}
\hline \multirow[b]{2}{*}{ Total } & \multicolumn{2}{|l|}{ No } & \multicolumn{2}{|l|}{ Yes } & \multirow{2}{*}{\multicolumn{2}{|c|}{ Management Practices }} \\
\hline & $\%$ & Frequency & $\%$ & Frequency & & \\
\hline $\begin{array}{l}150 \\
(100 \%)\end{array}$ & $55.3 \%$ & 83 & $44.7 \%$ & 67 & $\begin{array}{l}\text { Initial Measures } \\
\text { The drug infusion should be } \\
\text { stopped. }\end{array}$ & 14 \\
\hline $\begin{array}{l}150 \\
(100 \%)\end{array}$ & $55.3 \%$ & 83 & $44.7 \%$ & 67 & $\begin{array}{l}\text { Disable the infusion equipment but } \\
\text { leave the venous catheter in place. }\end{array}$ & 15 \\
\hline $\begin{array}{l}150 \\
(100 \%)\end{array}$ & $46.7 \%$ & 70 & $53.7 \%$ & 80 & $\begin{array}{l}\text { Aspire } 5-10 \mathrm{~mL} \text { of blood into the } \\
\text { venous catheter to remove as much } \\
\text { extravasated substance as possible. }\end{array}$ & 16 \\
\hline $\begin{array}{l}150 \\
(100 \%\end{array}$ & $52.3 \%$ & 78 & $48.7 \%$ & 72 & Withdraw the venous catheter & 17 \\
\hline $\begin{array}{l}150 \\
(100 \%)\end{array}$ & $49.3 \%$ & 74 & $50.7 \%$ & 76 & $\begin{array}{l}\text { Apply topical DMSO } 99 \% \text { to the } \\
\text { infected region twice. Allow it to } \\
\text { dry completely before applying } \\
\text { topical DMSO } 99 \% \text { every } 6 \text { hours } \\
\text { for } 14 \text { days. }\end{array}$ & 18 \\
\hline $\begin{array}{l}150 \\
(100 \%)\end{array}$ & $40.7 \%$ & 61 & $59.3 \%$ & 89 & $\begin{array}{l}\text { General Measures } \\
\text { Raise the impacted extremity } \\
\text { above the heart's height. }\end{array}$ & 19 \\
\hline $\begin{array}{l}150 \\
(100 \%)\end{array}$ & $43.3 \%$ & 65 & $56.7 \%$ & 85 & $\begin{array}{l}\text { If required, pharmacologic therapy } \\
\text { with or without heat or cold } \\
\text { treatment may be repeated after } 12 \\
\text { and } 24 \text { hours. }\end{array}$ & 20 \\
\hline
\end{tabular}

Above table show that $44.7 \%$ participants were know that stop drug infusion during chemotherapy and $53.7 \%$ were know that aspire $5-10 \mathrm{ml}$ of blood through the venous catheter to extract the maximum quantity of extravagated drug. $50.7 \%$ participants know that topical DMSO $99 \%$ on the affected area should be apply and 59.3 were know that affected area must be raised over the height of heart. 
International Journal of Health, Medicine and Nursing Practice

ISSN 2710-1150 (Online)

Vol. 3, Issue No. 3, pp 44- 57, 2021

WwW.carijournals.org

Table 4: significant association between educations with Nurses' knowledge of preventive strategies:

\begin{tabular}{|c|c|c|c|c|c|c|c|}
\hline $\begin{array}{c}\text { p- } \\
\text { value }\end{array}$ & $\mathbf{X}^{2}$ & $(\%)$ & No & $(\%)$ & Yes & Preventive strategies & \\
\hline \multicolumn{7}{|c|}{$\begin{array}{l}\text { Site of insertion } \\
\text { Cannula } \\
\text { It's impossible to u }\end{array}$} & 7 \\
\hline \multirow[t]{2}{*}{.021} & 7.741 & 1 & 2 & 50.3 & 75 & Yes & \\
\hline & & & & 49.7 & 74 & No & \\
\hline \multicolumn{7}{|c|}{ Use of large veins. } & 8 \\
\hline \multirow{2}{*}{.503} & 1.373 & 1 & 2 & 52.3 & 78 & Yes & \\
\hline & & & & 47.7 & 71 & No & \\
\hline \multicolumn{7}{|c|}{ Cannulation over joints, the inner elbow, and the lower extremities should be avoided. } & 9 \\
\hline \multirow[t]{2}{*}{.334} & 2.194 & 1 & 2 & 53.7 & 80 & Yes & \\
\hline & & & & 46.3 & 69 & No & \\
\hline \multicolumn{7}{|c|}{ Avoid veins in the antecubital fossa and on the dorsum of the hand. } & 10 \\
\hline \multirow[t]{2}{*}{.000} & 20.152 & 1 & 2 & 69.3 & 104 & Yes & \\
\hline & & & & 30.7 & 46 & No & \\
\hline \multicolumn{7}{|c|}{ Cannulation should be avoided if lymphedema is present. } & 11 \\
\hline \multirow[t]{2}{*}{.025} & 7.343 & 1 & 2 & 60.0 & 90 & Yes & \\
\hline & & & & 40.0 & 60 & No & \\
\hline \multicolumn{7}{|c|}{ Butterfly' needles must not be used. } & 12 \\
\hline \multirow[t]{2}{*}{.002} & 12.342 & 1 & 2 & 43.3 & 65 & Yes & \\
\hline & & & & 56.7 & 85 & No & \\
\hline \multicolumn{7}{|c|}{ For long-term infusions (12-24 hours), central venous access can be used. } & 13 \\
\hline \multirow[t]{2}{*}{.873} & .271 & 1 & 2 & 54.7 & 82 & Yes & \\
\hline & & & & 45.3 & 68 & No & \\
\hline \multicolumn{7}{|c|}{$\begin{array}{l}\text { Initial Measures } \\
\text { The drug infusion should be stopped. }\end{array}$} & 14 \\
\hline \multirow[t]{2}{*}{.000} & 24.439 & 1 & 2 & 44.7 & 67 & Yes & \\
\hline & & & & 55.3 & 83 & No & \\
\hline \multicolumn{7}{|c|}{ Remove the infusion equipment but leave the venous catheter in place. } & 15 \\
\hline \multirow[t]{2}{*}{.543} & 1.222 & 1 & 2 & 44.7 & 67 & Yes & \\
\hline & & & & 55.3 & 83 & No & \\
\hline \multicolumn{7}{|c|}{$\begin{array}{l}\text { To remove the most amount of extravasated drug, aspirate } 5-10 \mathrm{ml} \text { of blood through the } \\
\text { venous catheter. }\end{array}$} & 16 \\
\hline \multirow[t]{2}{*}{.006} & 10.117 & 1 & 2 & 53.7 & 80 & Yes & \\
\hline & & & & 46.7 & 70 & No & \\
\hline \multicolumn{7}{|c|}{ Withdraw the venous catheter } & 17 \\
\hline \multirow[t]{2}{*}{.116} & 4.301 & 1 & 2 & 48.7 & 72 & Yes & \\
\hline & & & & 52.3 & 78 & No & \\
\hline
\end{tabular}


International Journal of Health, Medicine and Nursing Practice

ISSN 2710-1150 (Online)

Vol. 3, Issue No. 3, pp 44- 57, 2021

$\underline{\text { www.carijournals.org }}$

\begin{tabular}{|c|c|c|c|c|c|c|c|}
\hline $\begin{array}{l}\text { Doub } \\
\text { apply }\end{array}$ & $\begin{array}{l}\text { he affe } \\
\text { topica }\end{array}$ & d & n & $\begin{array}{l}\text { h topi } \\
\text { ery } 6\end{array}$ & al I & $\begin{array}{l}\text { SO } 99 \% \text {. Allow it to dry completely before } \\
\text { or } 14 \text { days. }\end{array}$ & 18 \\
\hline .010 & 9.134 & 1 & 2 & 50.7 & 76 & Yes & \\
\hline & & & & 49.3 & 74 & $\mathrm{No}$ & \\
\hline $\begin{array}{l}\text { Gene } \\
\text { Raise }\end{array}$ & $\begin{array}{l}\text { Meast } \\
\text { injure }\end{array}$ & es & & eq & 1. & height of the heart. & 19 \\
\hline .027 & 7.243 & 1 & 2 & 59.3 & 89 & Yes & \\
\hline & & & & 40.7 & 61 & $\mathrm{No}$ & \\
\hline $\begin{array}{l}\text { After } \\
\text { be rep }\end{array}$ & $\begin{array}{l}\text { and } 24 \\
\text { ted if } n\end{array}$ & $5 S$ & ho & logi & the & y with or without heat or cold treatment may & 20 \\
\hline .242 & 2.835 & 1 & 2 & 56.7 & 85 & Yes & \\
\hline & & & & 43.3 & 65 & No & \\
\hline
\end{tabular}

Chi-square analysis showed that there were a significant association between educations with Nurses' knowledge of preventive strategies. Use of central venous in case of peripheral access is difficult values $\mathrm{x}^{2}(7.741)=.021, \mathrm{p}>0.5$ but there is no significant association between education with Avoid veins on the antecubital fossa or on the dorsum of the hand results are shown in the (Table \#04).

\section{DISCUSSION}

Nursing staff play an important part throughout administering chemotherapy especially post and. pre assessment, avoid or reduce planned problems. The overarching target is patient care, and It's a part of what nurses do on a regular basis. In order to maintain a secure environment, In order to operate successfully, It is important that the nurses possess adequate expertise. Recent evidencebased guidelines help people be more mindful of what they should do and how they should do it. The aim of this cross-sectional research was to find out how much oncology nurses knew regarding chemotherapy. Lifestyle factors, prevention steps, and treatment of extravasation injuries.

The present study report show that, nurses had adequate understanding of the concept of extravasation, and half of them knew the symptoms correctly as well as a troubling lack of information about several risk factors, were identified. $62.0 \%$ percent of the participants in the present sample Participants confirmed that they did not gain any further knowledge regarding extravasation of cancer patients. Inability of Identifying risk factors may have an impact on the quality of nursing care, so it's important to do so. Chemotherapy extravasation is a common occurrence that can have a negative impact on nursing care this study compare to the Sharour, L. A. study. According to ESMO-EONS recommendations, knowledge of prevention methods was split into three categories: location of injection, cannula features, and technique. The nurses said that they had little knowledge of the injection site and cannula characteristics. According to the survey, 53.7 percent of nurses were unaware that cannula cannot insert on any joint or lower extremities or on the dorsum of the hand could be prevented, and more than 56.7 percent of nurses had misconceptions concerning butterfly cannulas, compact cannulas, and the use of central venous access for infusions running faster beyond 12-24 hours. This results compare with the Sharour,L.A study. The present study show that $57.3 \%$ of participants were aware that tingling, swelling, pain, discomfort were common sign after chemotherapy process these compare to the 
Custódio, C. d. S. study. The present study show that $49.3 \%$ participant were aware that invasive ulceration occur after 1-4 week of chemotherapy and 59.3\% participants were aware that raised the affected area over the height of heart which compare to the Sharour 1.a study. The participants' knowledge of recent evidence-based extravasation control techniques was found to be extremely limited, particularly in relation to individual treatment and general measures components, according to the findings of the current research.

Although some important and useful findings, the present analysis has certain shortcomings, such as the fact that the results were focused on a subjective assessment of current experience. Future studies using observation techniques is encouraged. While the new research centered only on nurses, it is advised that other health professionals' expertise, such as pharmacists, be assessed.

\section{Conclusion}

Likely, the recent research serves as the basis of experience and expertise of extravasation treatment for oncology nurses. Surprisingly, nurses' understanding of management methods was woefully lacking. This may have an effect on the level of care given to patients with the aid of extravasation Education, lectures, and conferences are held on a regular basis. Oncology nurses should participate in this study. Specific policy, new evidence-based standards, and written guidance can be used to improve nurses' skills and enhance their competencies.

\section{Acknowledgement}

Thankful all patient who participats in this study. I also thankful to hospital administration.

\section{Reference}

Agbessi, O., et al. (2015). "Extended arm necrosis by chemotherapy drugs extravasation." 4(147): 2.

Al Qadire, M. and M. J. C. n. r. Al Khalaileh quality of life among Jordanian cancer

(2016). "Prevalence of symptoms and patients." 25(2): 174-191.

Azoulay, E., et al. (2017). "The Intensive Care Medicine research agenda on critically ill oncology and hematology patients." 43(9): 1366-1382.

Ferlay, J., et al. (2015). "Cancer incidence and mortality worldwide: sources, methods and major patterns in GLOBOCAN 2012." 136(5): E359-E386.

Fidalgo, J. P., et al. (2015). "Management of chemotherapy extravasation: ESMOEONS clinical practice guidelines." 16(5): 528-534.

Hameed, S., et al. (2019). "Analysis of the Prevalence of cancer in Faisalabad: A single centre study." 3(2): 114-118.

Mileder, L. P., et al. (2019). "Paramedics' Newborn Life Support Knowledge and Skills Before and After a Targeted Simulation-Based Educational Intervention." Frontiers in pediatrics 7: 132.

Onesti, M. G., et al. (2017). "Chemotherapy extravasation management: 21-year experience." 79(5): 450-457. 
Papa, D., et al. (2015). "P53 Assessing Hellenic oncology nurses' knowledge and practice about chemotherapy handling and administration." (14): S38-S39.

Pluschnig, U., et al. (2015). "Outcome of chemotherapy extravasation in a large patient series using a standardised management protocol." 23(6): 1741-1748.

Somayaji, S., et al. (2018). "Extent of extravasation injury among patients receiving parenteral chemotherapy." 21: $\quad$ S20. 